ARTIKEL

ANALISIS KESESUAIAN MATERI PADA BUKU TEKS

BAHASA INDONESIA DENGAN KOMPETENSI DASAR

PADA SILABUS BAHASA INDONESIA KELAS

VII SMP KURIKULUM 2013 (EDISI REVISI)

Oleh

Atika Sadariah Nasution

NIM 2131111009

Dosen Pembimbing Skripsi

Drs. Azhar Umar, M.Pd.

Telah Diverifikasi dan Dinyatakan Memenuhi Syarat untuk Diunggah pada Jurnal Online

Editor,

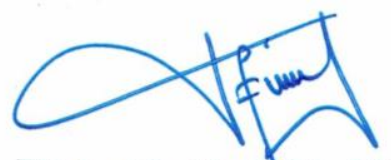

Fitriani Lubis, S.Pd., M.Pd. NIP 197708312008122001
Medan, Juli 2017

Menyetujui :

Dosen Pembimbing Skripsi,

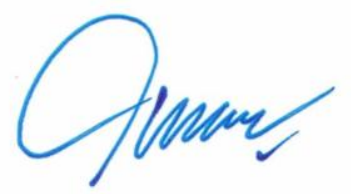

Drs. Azhar Umar, M.Pd.

NIP 196006111985031002 


\title{
ANALISIS KESESUAIAN MATERI PADA BUKU TEKS \\ BAHASA INDONESIA DENGAN KOMPETENSI DASAR \\ PADA SILABUS BAHASA INDONESIA KELAS VII \\ SMP KURIKULUM 2013 (EDISI REVISI)
}

\begin{abstract}
Oleh
Atika Sadariah Nasution

Drs. Azhar Umar, M.Pd.

Penelitian ini bertujuan untuk mengetahui kesesuaian materi pada buku teks bahasa Indonesia dengan Kompetensi Dasar pada silabus bahasa Indonesia kelas VII SMP kurikulum 2013 (edisi revisi) dengan indikator penilaian pada aspek relevansi, konsistensi, dan kecukupuan materi. Objek penelitian ini adalah silabus kelas VII SMP dan buku teks bahasa Indonesia kelas VII SMP Kurikulum 2013 (edisi revisi). Instrumen penelitian ini adalah lembar penilaian kesesuaian materi dengan Kompetensi Dasar pada silabus berdasarkan aspek relevansi, konsistensi, dan kecukupan. Hasil analisis kesesuaian materi pada buku teks bahasa Indonesia dengan Kompetensi Dasar secara keseluruhan skor indikator penilaian pada aspek relevansi $91,66 \%$ termasuk kriteria sangat baik, aspek konsistensi $86,9 \%$ dan 96,42\% termasuk kriteria sangat baik, dan pada aspek kecukupan termasuk kriteria sangat baik $96,42 \%$ termasuk kriteria sangat baik dan $96,42 \%$ termasuk kriteria sangat baik.

Artinya, kesesuaian materi pada buku teks bahasa Indonesia dengan Kompetensi Dasar pada silabus kelas VII SMP kurikulum 2013 (edisi revisi) berdasarkan aspek relevansi, konsistensi, dan kecukupan termasuk dalam kriteria sangat baik. Maka dapat disimpulkan bahwa buku teks bahasa Indonesia kelas VII SMP Kurikulum 2013 yang diterbitkan oleh Kementrian Pendidikan dan Kebudayaan sangat baik dan dapat dijadikan sebagai bahan ajar dalam kegiatan belajar mengajar di sekolah.
\end{abstract}

Kata kunci: Analisis Buku Teks Bahasa Indonesia, Kompetensi Dasar, Relevansi, Konsistensi, dan Kecukupan

\section{PENDAHULUAN}

Untuk mewujudkan fungsi pendidikan pada kurikulum 2013 diperlukan usaha untuk meningkatkan kualitas proses pembelajaran pada tingkat satuan pendidikan. Kualitas yang diharapakan meliputi berbagai macam komponen, diantaranya adalah 
pendidik, peserta didik, dan bahan ajar. Menurut Hanum (dalam Pannen, 2015:1) Bahan ajar merupakan bahan atau materi pelajaran yang disusun secara sistematis, yang digunakan guru dan siswa dalam proses pembelajaran.Bahan ajar adalah segala bentuk bahan yang digunakan untuk membantu guru atau instruktur dalam melaksanakan proses pembelajaran di kelas merupakan salah satu komponen yang memegang peranan penting dalam pembelajaran. Salah satu bahan ajar yang dibutuhkan adalah buku teks.

Keberadaan buku teks sangat menunjang fungsi pendidikan nasional. Buku teks hinga kini masih dianggap sebagai bahan ajar yang paling utama. Ini terbukti hampir di berbagai instansi pendidikan, dari jenjang yang paling dasar hingga yang paling tinggi, pada umumnya menggunakan buku teks sebagai bahan ajar utamanya. Berdasarkan Peraturan Badan Standar Nasional Pendidikan (BSNP) mengenai kelayakan buku teks pelajaran yang digunakan di sekolah-sekolah harus memiliki kebenaran isi, penyajian yang sistematis, penggunaan bahasa dan keterbacaan yang baik, dan grafika yang fungsional yang disesuaikan dengan Kompetensi Inti (KI) dan Kompetensi Dasar (KD) yang dikeluarkan oleh kurikulum 2013.

Pada kenyataannya banyak masalah yang terjadi di lapangan mengenai buku ajar yang disiapkan oleh pemerintah tidak memiliki kesesuian antara materi pada bahan ajar tersebut dengan KI dan KD yang telah ditentukan. Berdasarkan hasil wawancara dan observasi di SMP Negeri 3 Perbaungan pada semester ganjil tahun pembelajaran 2016/2017 kelas VII-A dengan Kompetensi Dasar 3.4 Menelaah struktur dan kebahasaan teks narasi (cerita fantasi) yang dibaca dan didengar dan 4.4 Menyajikan gagasan kreatif dalam bentuk cerita fantasi secara lisan dan tulis dengan memperhatikan struktur sedangkan materi yang tercantum pada buku teks bahasa Indonesia yaitu teks deskripsi sehingga Kompetensi Dasar pada silabus tidak sesuai dengan materi yang ada pada buku teks Bahasa Indonesia Wahana Pengetahuan kelas VII SMP. Karena ketidaksesuaian tersebut berdampak negatif terhadap terganggunya kegiatan pembelajaran siswa dan menurunnya prestasi belajar siswa.

Sejalan dengan masalah tersebut., Wismi Sari (Sarah, 2016:3) seorang instruktur nasional pelatihan materi kurikulum 2013 mengatakan bahwa isi materi pelajaran bahasa Indonesia terlalu sederhana jika dibandingkan dengan tujuan 
pembelajaran yang harus mendorong siswa mambangun cara berfikir untuk memecahkan masalah dan mengelola kelompok kerja. Selain itu, sistematika temanya kurang sistematis dengan yang ada pada KI dan KD pada silabus. Apabila Kompetensi Inti dan Kompetensi Dasar pada silabus memiliki kesesuaian yang rendah maka kompetensi yang diharapkan sulit tercapai dan tujuan pengemabangan fungsi kurikulum 2013 tidak tercapai maksimal. Oleh karena itu, peneliti merasa perlu untuk menganalisis kesesuaian materi pada buku teks bahasa Indonesia dengan Kompetensi Dasar pada Silabus Kurikulum 2013 (edisi revisi).

\section{METODE PENELITIAN}

Penelitian ini menggunakan metode penelitian kualitatif karena menurut Syaiodih Sukmadinata (2012:60) "Penelitian kualitatif (qualitative research) adalah suatu penelitian yang ditujukan untuk mendeskripsikan dan menganalisa fenomena, peristiwa, aktivitas sosial, sikap, kepercayaan, persepsi, pemikiran orang secara individual maupun kelompok." Menurut Bangun (2003:47) "Penelitian kualitatif deskriptif adalah cendrung disebut dengan analasis 'text". Badan Standar Nasional Pendidikan (Pratiwi, 2013:47) menyatakan bahwa untuk mengetahaui kesesuaian materi pada buku teks bahasa Indonesia dengan KD pada silabus Bahasa Indonesia kelas VII SMP kurikulum 2013 (edisi revisi) harus beradsarkan aspek relevansi, konsistensi, dan kecukupan.

Kemudian, untuk mempermudah peneliti ketika mengambil kesimpulan mengenai kesesuaian materi pada buku teks bahasa Indonesia dengan KD pada silabus Bahasa Indonesia kelas VII SMP kurikulum 2013 (edisi revisi) peneliti menggunakan alat bantu rumus untuk pemberian skor pada setiap aspek.

\section{HASIL PENELITIAN DAN PEMBAHASAN}

\section{Hasil Penelitian}

Hasil penelitian kesesuaian materi pada buku teks bahasa Indonesia kelas VII SMP dengan Kompetensi Dasar pada silabus kurikulum 2013 (edisi revisi) berdasarkan aspek relevansi, konsistensi, dan kecukupan dijelaskan seperti di bawah ini: 


\section{Kesesuaian Materi Buku Teks Bahasa Indonesia dengan Kompetensi Dasar Pada Silabus \\ 1.1 Kesesuaian Materi Buku Teks Bahasa Indonesia dengan Kompetensi Dasar Pada Silabus Pada Aspek Relevansi}

Aspek relevansi terdiri atas satu sub aspek kelayakan isi dengan tiga indikator penilaian. Indikator penilaian kesesuaian materi pada buku teks dengan Kompetensi Dasar memperoleh jumlah skor 52, indikator penilaian kemutakhiran isi atau materi memperoleh skor 46 , dan indikator penilaian keberagaman nilai memperoleh skor 56. Pada sub aspek ini, jumlah skor dari seluruh indikator penilaian adalah 154. Sedangkan, skor maksimalnya yang dapat dicapai pada sub aspek adalah 168. Maka, presentase yang diperoleh pada sub aspek ini adalah $91,66 \%$ dan termasuk dalam kriteria sangat baik.

\subsection{Kesesuaian Materi Buku Teks Bahasa Indonesia dengan Kompetensi Dasar Pada Silabus Pada Aspek Konsistensi}

Aspek konsistensi terdiri atas dua sub aspek dengan tujuh indikator penialian, yaitu:

1. Sub aspek cakupan materi memiliki tiga indikator penilaian, yaitu indikator penilaian kelengkapan ruang lingkup materi memperoleh skor 52, indikator penilaian keluasan materi/makna memperoleh skor 50, dan indikator penilaian kedalaman materi/makna memperoleh skor 44. Pada sub aspek ini, jumlah skor dari seluruh indikator penilaian adalah 146. Sedangkan, skor maksimalnya yang dapat dicapai pada sub aspek yang pertama adalah 168 . Maka, presentase yang diperoleh pada sub aspek pertama adalah 86,9\% dan termasuk dalam kriteria sangat baik.

2. Sub aspek yang kedua keakuratan materi memiliki empat indikator penilaian, yaitu indikator penilaian kebenaran fakta memperoleh skor 56, indikator penilaian kebenaran konsep memperoleh skor 56, indikator penilaian kebenaran teori memperoleh skor 54, dan indikator penilaian kebenaran prosedur memperoleh skor 50. Pada sub aspek ini, jumlah skor dari seluruh indikator penilaian adalah 216. Sedangkan, skor maksimal yang dapat dicapai sub aspek kedua adalah 224. Maka, presentase yang diperoleh pada sub aspek kedua adalah 96,42\% dan termasuk dalam kriteria sangat baik. 


\subsection{Kesesuaian Materi Buku Teks Bahasa Indonesia dengan Kompetensi Dasar Pada Silabus Pada Aspek Kecukupan}

Aspek kecukupan terdiri atas dua sub aspek dengan delapan indikator penialian, yaitu:

1. Sub aspek teknik penyajian memiliki tiga indikator penilaian, yaitu indikator penilaian penyajian materi secara utuh memperoleh skor 54, indikator penilaian kelogisan sajian materi memperoleh skor 54, dan indikator penilaian keruntutan sajian konsep memperoleh skor 54. Pada sub aspek ini, jumlah skor dari seluruh indikator penilaian adalah 162. Sedangkan, skor maksimalnya yang dapat dicapai pada sub aspek yang pertama adalah 168 . Maka, presentase yang diperoleh 96,42\% termasuk kriteria sangat baik.

2. Sub aspek yang kedua penyajian pembelajaran memiliki lima indikator penilaian, yaitu indikator penilaian berpusat pada peserta didik memperoleh skor 54, indikator penilaian mendorong eksplorasi memperoleh skor 54, indikator penilaian memberikan peluang apresiasi memperoleh skor 54, indikator penilaian memacu kreativitas memperoleh skor 54, dan indikator penilaian memunculkan umpan balik memperoleh skor 54. Pada sub aspek ini, jumlah skor dari seluruh indikator penilaian adalah 270. Sedangkan, skor maksimal yang dapat dicapai sub aspek kedua adalah 280. Maka, presentase yang diperoleh pada sub aspek kedua adalah 96,42\% dan termasuk dalam kriteria sangat baik.

\section{Pembahasan}

1. Kesesuaian Materi Buku Teks Bahasa Indonesia dengan Kompetensi Dasar Pada Silabus

\subsection{Kesesuaian Materi Buku Teks Bahasa Indonesia dengan Kompetensi Dasar Pada Silabus Pada Aspek Relevansi}

Kesesuaian materi pada buku teks bahasa Indonesia dengan Kompetensi

Dasar pada silabus kurikulum 2013 (edisi revisi) pada aspek relevansi dengan sub aspek kelayakan isi pada indikator kesesuaian isi buku dengan KD memperoleh skor 7 pada Bab 1,2,3,4,6,7, dan 8 karena memiliki kesesuaian dengan KD. Namun, pada Bab 5 memperoleh skor 5 karena pada KD 3.13 mengidentifikasi 
informasi berupa pilihan kata dari puisi rakyat tidak dicantumkan atau tidak ditemukan.

Kesesuaian materi pada buku teks bahasa Indonesia dengan Kompetensi Dasar pada silabus kurikulum 2013 (edisi revisi) pada aspek relevansi dengan sub aspek kelayakan isi pada indikator kemutakhiran materi memperoleh skor 5 pada Bab 1,2,3,4,5,6,7, dan 8 karena materi dan contoh teks yang dinatumkan tidak terbaru atau up to date. Kesesuaian materi pada buku teks bahasa Indonesia dengan Kompetensi Dasar pada silabus kurikulum 2013 (edisi revisi) pada aspek relevansi dengan sub aspek kelayakan isi pada indikator keberagaman nilai memperoleh skor 7 pada Bab 1,2,3,4,5,6,7, dan 8 karena dari materi dan contoh teks yang dicantumkan tidak merusak nilai-nilai moral pada siswa.

\subsection{Kesesuaian Materi Buku Teks Bahasa Indonesia dengan Kompetensi Dasar Pada Silabus Pada Aspek Konsistensi}

Kesesuaian materi pada buku teks bahasa Indonesia dengan Kompetensi Dasar pada silabus kurikulum 2013 (edisi revisi) pada aspek konsistensi dengan sub aspek cakupan materi pada indikator kelengkapan ruang lingkup materi memperoleh skor 7 pada Bab 1,3,4,6,7,dan 8. Namun, pada Bab 2 mamperoleh skor 5 karena pada Bab ini hanya menjelaskan mengenai unsur tokoh, alur, dan latar cerita fantasi tanpa menjelaskan unsur-unsur ceirta fantasi lebih lengkap, luas, dan dalam. Bab 5 memperoleh skor 5 karena materi mengenai rima pada pantun hanya dalam bentuk penugasan saja tidak dilandasi pembahasan materi.

Kesesuaian materi pada buku teks bahasa Indonesia dengan Kompetensi Dasar pada silabus kurikulum 2013 (edisi revisi) pada aspek konsistensi dengan sub aspek cakupan materi pada indikator keluasan materi memperoleh skor 7 pada $\mathrm{Bab}$ 1,3,4,5,6, dan 7. Bab 2 memperoleh skor 5 karena mengenai struktur dan kebahasaan cerita fantasi tanpa menjelaskan unsur-unsur teks narasi dalam bentuk materi dan Bab 8 memperoleh skor 3 karena pada Bab ini hanya sebatas materi mengenai langkah merangkum buku fiksi dan nonfiksi serta memberikan komentar pada isi buku fiksi dan nonfiski. 
Kesesuaian materi pada buku teks bahasa Indonesia dengan Kompetensi Dasar pada silabus kurikulum 2013 (edisi revisi) pada aspek konsistensi dengan sub aspek cakupan materi pada indikator kedalaman materi memperoleh skor 7 pada Bab 1,3, dan 4, memperoleh skor 5 pada Bab 2,5,6, dan 7, dan memperoleh skor 3 pada Bab 8 karena pada Bab ini hanya sebatas materi mengenai langkah merangkum buku fiksi dan nonfiksi serta memberikan komentar pada isi buku fiksi dan nonfiski.

Kesesuaian materi pada buku teks bahasa Indonesia dengan Kompetensi Dasar pada silabus kurikulum 2013 (edisi revisi) pada aspek konsistensi dengan sub aspek keakuratan materi pada indikator kebenaran fakta memperoleh skor 7 pada Bab 1,2,3,4,5,6,7, dan 8. Pada indikator kebenaran konsep memperoleh skor 7 pada Bab 1,2,3,4,5,6,7, dan 8. Pada indikator kebenaran teeori memperoleh skor 7 pada Bab 1,3,4,5,6,7, dan 8. Namun, pada Bab 2 memperoleh skor 5 karena pada halaman 58 teori menentukan unsur-unsur instrinsik cerita fantasi disajikan hanya sebatas tokoh/penokohan, pesan dan alur. Pada indikator kebenaran prosedur memperoleh skor 7 pada Bab 1,2,5,7, dan 8. Pada Bab 3,4, dan 8 memperoleh skor 5 karena seperti di Bab 8 hanya sebatas materi mengenai langkah merangkum buku fiksi dan nonfiksi serta memberikan komentar pada isi buku fiksi dan nonfiski.

\subsection{Kesesuaian Materi Buku Teks Bahasa Indonesia dengan Kompetensi Dasar Pada Silabus Pada Aspek Kecukupan}

Kesesuaian materi pada buku teks bahasa Indonesia dengan Kompetensi Dasar pada silabus kurikulum 2013 (edisi revisi) pada aspek kecukupan dengan sub aspek teknik penyajian pada indikator penyajian secara utuh, kelogisan sajian materi, dan keruntutan sajian konsep memperoleh skor 7 pada Bab 1,2,3,4,5,6, dan 7. Namun, pada Bab 8 memperoleh skor 5 karena Penyajian materi mengenai mengenali unsur buku fiksi dna nonfiksi hanya sebatas kegiatan penyajiaannya tidak lengkap, tidak dalam, tidak utuh, dan tidak berdasarkan tuntutan Kompetensi Dasar materi disajikan teratur dan beruntut mulai dari yang mudah hingga sulit secara utuh. 
Kesesuaian materi pada buku teks bahasa Indonesia dengan Kompetensi Dasar pada silabus kurikulum 2013 (edisi revisi) pada aspek kecukupan dengan sub aspek penyajian pembelajaran pada indikator berpusat pada peserta didik, mendorong eksplorasi, memberikan peluang apresiasi, memacu kreativitas, dan memunculkan umpan balik/evaluasi pada Bab 1,2,3,4,5,6, dan 7 memperoleh skor 7. Namun, Bab 8 memperoleh skor 5 karena setiap aspek penilaian pada Bab 8 kurang baik dan tidak memiliki kesesuaian dengan Kompetensi Dasar 3.9, 4.9, 3.10, dan 4.10. Pada Bab ini yang dibahas materinya hanya seputar bagaimana cara mengomentari isi buku fiksi dn nonfiksi dengan penjelasan langkahlangkahnya.

\section{PENUTUP}

Setelah melakukan analisis terhadap kesesuaian materi pada buku teks bahasa Indonesia dengan Kompetensi Dasar pada silabus kelas VII SMP kurikulum 2013 (edisi revisi) yang diterbitkan oleh Kementrian Pendidikan dan Kebudayaan dapat disimpulkan sebagai berikut.

\subsection{Kesesuaian Materi Buku Teks Bahasa Indonesia dengan Kompetensi Dasar Pada Silabus Pada Aspek Relevansi}

Hasil analisis kesesuaian materi buku teks bahasa Indonesia dengan Kompetensi Dasar berdasarkan indikator penilaian pada aspek relevansi dengan indikator kesesuian isi buku dnegan KD memperoleh skor 54, indikator penilaian kemutakhiran materi memperoleh skor 44, dan indikator penilaian keberagaman nilai memperoleh skor 56. Pada sub aspek ini, jumlah skor dari seluruh indikator penilaian adalah 156. Sedangkan, skor yang dapat dicapai pada sub aspek adalah 168. Maka, presentase yang diperoleh pada sub aspek ini adalah 91,66\% dan termasuk dalam kriteria sangat baik.

\subsection{Kesesuaian Materi Buku Teks Bahasa Indonesia dengan Kompetensi Dasar Pada Silabus Pada Aspek Konsistensi}

Aspek konsistensi terdiri atas dua sub aspek dengan tujuh indikator penialian. Pertama, sub aspek cakupan materi memiliki tiga indikator penilaian, yaitu indikator penilaian kelengkapan ruang lingkup materi memperoleh skor 52, 
indikator penilaian keluasan materi/makna memperoleh 50, dan indikator penilaian kedalaman materi/makna memperoleh 44. Pada sub aspek ini, jumlah skor dari seluruh indikator penilaian adalah 156. Sedangkan, skor maksimalnya yang dapat dicapai pada sub aspek yang pertama adalah 168. Maka, presentase yang diperoleh pada sub aspek pertama adalah $86,9 \%$ dan termasuk dalam kriteria sangat baik baik. Sub aspek yang kedua cakupan materi memiliki empat indikator penilaian, yaitu indikator penilaian kebenaran fakta memperoleh 56, indikator penilaian kebenaran konsep memperoleh 56, indikator penilaian kebenaran teori memperoleh 54, dan indikator penilaian kebenaran prosedur memperoleh 50 . Sedangkan, skor maksimal yang dapat dicapai sub aspek kedua adalah 224. Maka, presentase yang diperoleh pada sub aspek kedua adalah 96,42\% dan termasuk dalam kriteria sangat baik.

\subsection{Kesesuaian Materi Buku Teks Bahasa Indonesia dengan Kompetensi Dasar Pada Silabus Pada Aspek Kecukupan}

Aspek kecukupan terdiri atas dua sub aspek dengan delapan indikator penialian. Pertama, sub aspek teknik penyajian memiliki tiga indikator penilaian, yaitu indikator penilaian penyajian materi secara utuh memperoleh skor 54, indikator penilaian kelogisan sajian materi memperoleh skor 54, dan indikator penilaian keruntutan sajian konsep memperoleh skor 54. Pada sub ini, jumlah skor dari seluruh indikator penilaian adalah 162. Sedangkan, skor maksimalnya yang dapat dicapai pada sub aspek yang pertama adalah 168. Maka, presentase yang diperoleh 96,42\% termasuk kriteria sangat baik. Sub aspek yang kedua penyajian pembelajaran memiliki lima indikator penilaian, yaitu indikator penilaian berpusat pada peserta didik memperoleh skor 54, indikator penilaian mendorong eksplorasi memperoleh skor 54, indikator penilaian memberikan peluang apresiasi memperoleh skor 54, indikator penilaian memberika kreativitas memperoleh skor 54, dan indikator penilaian memunculkan umpan balik memperoleh skor 54. Pada sub aspek ini, jumlah skor dari seluruh indikator penilaian adalah 270 Sedangkan, skor maksimal yang dapat dicapai sub aspek kedua adalah 280. Maka, presentase yang diperoleh pada sub aspek kedua adalah 96,42\% dan termasuk dalam kriteria sangat baik. 
Berdasarkan simpulan di atas kesesuaian materi pada buku teks bahasa Indonesia dengan Kompetensi Dasar pada silabus kurikulum 2013 (edisi revisi) dalam kategori sangat baik. Artinya, buku teks tersebut layak untuk digunakan dalam kegiatan pembelajaran.

\section{DAFTAR PUSTAKA}

Bungin, Burhan. 2003. Metode Penlitian Kualitatif. Jakarta: Grafindo Persada.

Hanum, Inayah. 2015. Pengembangan Bahan Ajar. Medan: Medan Press.

Nur Aisyah, Sarah. 2016. Skripsi: Analisis Buku Ajar Bahasa dan Sastra Indonesia Sekolah Menengah Atas (SMA) Kelas XII Kurikulum 2013. Medan: Unimed.

Pratiwi, Melia. 2013. Skripsi: Analisis Kesesuain Materi Buku Ajar Bahasa Indonesia SMP Kelas IX Kurikulum 2013. Medan: Unimed.

Sukmadinata, Syaiodih. 2012. Metode Penelitian. Bandung: PT Rosdakarya. 